\title{
Car Mikołaj II - heroizm i męczeństwo
}

\author{
Tomasz Kuprjanowicz \\ Uniwersytet Jagielloński \\ Warszawa, Polska \\ ORCID: 0000-0002-1706-2211 \\ t.kuprjanowicz@interia.pl
}

T. Kuprjanowicz, Tsar Nicholas II - heroism and martyrdom, Elpis, 21 2019: 21-25.

\begin{abstract}
In 2018, the Russian Orthodox Church solemnly commemorates the 100-year anniversary of the tragic events in Yekatarinburg. Emperor Nicholas II, Empress Alexandra, Prince Alexei, and Princesses Olga, Tatiana, Maria and Anastasia. At the Jubilee Episcopal Council, which took place 13 -16 August, 2000 in Christ the Saviour Cathedral, the Rite of the Canonization of the New Martyrs and Confessors of Russia, both known and unknown in the world, but known to God was conducted. Among the glorified was the Imperial Family, including Emperor Nicholas II. In this article, we would like to remember Nicholas II and acknowledge him as a brave man and martyr.

Streszczenie: W 2018 roku Rosyjska Cerkiew Prawosławna uroczyście upamiętnia 100-lecie tragicznych wydarzeń w Jekaterynburgu. Ponieśli tam męczeńską śmierć imperator Mikołaj II, cesarzowa Aleksandra, carewicz Aleksy, wielkie księżne Olga, Tatiana, Maria i Anastazja. Na Biskupim Jubileuszowym Soborze, odbywającym się w Moskwie 13-16 sierpnia 2000 roku w świątyni Chrystusa Zbawiciela, został przyjęty Czyn o soborowej kanonizacji nowych męczenników i wyznawców rosyjskich, objawionych i nieobjawionych światu, ale znanych Bogu. W gronie wysławionych - Carska Rodzina, w jej składzie - car Mikołaj II. W artykule autor chciał wspomnieć osobę cara Mikołaja II i przyjrzeć się mu jako dzielnemu mężowi i męczennikowi.
\end{abstract}

Keywords: Tsar Nicholas II, Russia, Heroism, Martyrdom, Canonization

Slowa kluczowe: car Mikołaj II, Rosja, heroizm, męczeństwo, kanonizacja

W związku z określonym w pełni stanowiskiem Komisji Synodalnej w sprawie kanonizacji, że w przypadku Mikołaja II będzie on kanonizowany jako męczennik (wobec trudów wyrażonych „в страданиях, перенесенных Царской Семьей в заточении с кротостью, терпением и смирением, в их мученической кончине в Екатеринбурге”) ( Юбилейный Архиерейский Собор Русской Православной Церкви, 13-16 августа 2000 года. Сборник докладов и документов, Санкт-Петербург, 2000, s. 79), przebadana została wówczas cała jego biografia. Szczególnie przebadane zostały np. następujące zagadnienia: car Mikołaj II i wydarzenia z 9 stycznia 1905 roku; rodzina carska i G. J. Rasputin; przyczyny abdykacji cara Mikołaja II i prawosławne stanowisko wobec tego aktu; a także ostatnie dni rodziny carskiej. Logika cerkiewnej interpretacji podpowiada, że należało zbadać, gdzie znajduje się punkt odniesienia do wstąpienia cara Mikołaja na drogę męczennika. Nie było innej możliwości, bowiem jeżeli w odpowiedziach na wymienione zagadnienia ujrzymy wyłącznie udział Cerkwi w polemice ze światem, to należałoby w dostępnej formie wyjaśnić w ogóle istotę trudów ponoszonych przez świętych. Należałoby wyjaśnić możliwość ich upadku z ich późniejszą duchową przemianą, która będzie świadczyć o zwycięskiej drodze ku świętości. Wykład Jego Eminencji metropolity krutickiego i kołomieńskiego Juwenaliusza podczas Jubileuszowego Soboru Biskupów w 2000 roku zawierał okolicznościowe objaśnienie podstaw i motywacji pracy badawczej Komisji Synodalnej.
Należy dodać, że „в наш лукавый век необходимо применять дополнительные критерии при подходе к данной теме, учитывать обстоятельства эпохи" (Доклад митрополита Крутицкого и Коломенского Ювеналия, председателя Синодальной Комиссии по канонизации святых, 2000).

Owa konieczność, aby ,zastosować dodatkowe kryteria”, powinna stymulować nowe badania świętości cara-męczennika. Nie wchodząc w dyskusję z wnioskami komisji dotyczącymi kanonizacji, należy zauważyć, że ograniczenie się do trudów męczeńskich cara Mikołaja II w czasie po jego abdykacji nie jest dostatecznie uzasadnione, chociaż jest to forma bezdyskusyjnej definicji, która stanowi argument w polemice $\mathrm{z}$ oponentami. Poza tym w tejże kompromisowej definicji nie można nie zauważyć niejednoznaczności takich zasadniczych cech charakterystycznych jak tytułowanie świętego carem (w innych miejscach - imperatorem) i wskazanie na wcielanie przez niego w życie wartości ewangelicznych.

Tytułowanie męczennika Mikołaja carem w poczcie świętych powinno być rozumiane jako uznanie jego zwycięskich trudów nawet podczas sprawowania urzędu cara, lecz kanonizacja soborowa wskazuje tylko na miesiące w uwięzieniu, tj. po tym, gdy był już byłym carem i autokratą. Przy okazji, w ten sposób tytułuje go patriarcha Tichon w swoim kazaniu: „На днях совершилось ужасное дело: расстрелян бывший Государь Николай Александрович" (Акты Святейтего Тихона, Патриарха Московского и всея Руси, позднейтие документы и 
переписка о каноническом преемстве высшей церковной власти, 1994, s. 142). W momencie przerwania służby carskiej męczennik Mikołaj był rzeczywiście byłym carem, gdyż abdykacja była postrzegana przez społeczeństwo jako abdykacja dokonana (nawet pomimo oczywistych nieścisłości prawnych). Wykazanie statusu carskiego nie może być identyfikowane według pochodzenia (Ершов C. А., 2000, s. 12-13), mimo że pochodzenie Mikołaja II wywodzi się od wielkich książąt (Bbıcoyaŭший Манифест, „Петербургская газета” 9 мая, 1968 г., № 62, s. 1), a jego rodowa przynależność jest książęca. Nie był on nawet synem cara, a wnukiem; był bowiem synem carewicza Aleksandra Aleksandrowicza. W celu pełnego zrozumienia zagadnienia należy zauważyć, że Konstantynowiczowie, dzieci wielkiego księcia Konstantyna Konstantynowicza, były prawnukami imperatora Mikołaja I i stryjecznymi wnukami Aleksandra II, i nie są już wielkimi książętami oraz ich cesarskimi wysokościami, lecz zwykłymi książętami (tytuł czysto rodowy). To samo należy powiedzieć o Kiriłowiczach, dzieciach wielkiego księcia Kiriła (Cyryla) Władimirowicza. Z tego wynika, że tytułowanie męczennika Mikołaja carem, a nie księciem, wyraża uznanie przez Cerkiew początku jego świętych trudów w okresie jego panowania.

Przemyślane niedopowiedzenie jest również widoczne we wskazaniu na wcielanie w życie cara wartości ewangelicznych: „За многими страданиями, перенесенными Царской Семьей за последние 17 месяцев жизни, которая закончилась расстрелом в подвале Екатеринбургского Ипатьевского дома в ночь на 17 июля 1918 года, мы видим людей, искренне стремившихся воплотить в своей жизни заповеди Евангелия" (Доклад митрополиma..., 2000). Dodajmy: także wcielających.

Niekorzystne warunki życia w świecie, aby w pełni dążyć do ewangelicznych wartości, są proponowane tym, którzy w pełni dążą do owych wartości, tj. wybranych, mających na głowie wieniec męczeństwa, wyznania wiary i cierpienia. Metropolita Juwenaliusz mówił na Jubileuszowym Soborze Biskupów w 2000 roku tak: „Как политик и государственный деятель Государь поступал, исходя из своих религиозно-нравственных принципов”. I dalej: „Оценке подлежит, насколько то или иное лицо сумело воплотить в своей деятельности христианские идеалы”, ale „подводя итог изучению государственной и церковной деятельности последнего Российского Императора, Комиссия не нашла в одной этой деятельности достаточных оснований для его канонизации" (Доклад митрополита..., 2000). Trud poświadczony przez śmierć był niewystarczającą podstawą. Przymusowa śmierć imperatora Mikołaja w dniu pamięci innego zabitego, wielkiego księcia-męczennika Andrzeja Bogolubskiego to ostatnia data biografii, ale nie życia. Biografia ma swój koniec, ale nie życie, które jest drogą nie tylko ku wieczności, ale także w wieczności.

Ogólną charakterystyczną różnicą między biografią i życiem jest tendencyjny wybór historycznych świadectw o życiu i działalności człowieka. Tendencyjność życiowej kanwy jest określana według znanej reguły: to, co charak- teryzuje drogę wielkich czynów świętego. Tendencyjność biografii w związku z bezdyskusyjną historycznością faktów wychodzi poza ocenę ideologiczną. Na przykład, obok deklarowanej przez Mikołaja II pokojowej polityki zagranicznej w czasach sowieckich w jego biografii brakuje jego bezprecedensowej inicjatywy pokojowej z 1898 roku, dotyczącej powołania konferencji w celu omówienia zagadnień ochrony świata i zmniejszenia zasobów broni. Skutkiem tejże inicjatywy były pokojowe konferencje w Hadze w 1899 („Петербургская газета” 6-25 мая, 1899 г., №№ 122-140, s. 101-117) i 1907 roku. Ich postanowienia nie utraciły swego znaczenia i w naszych czasach, choć dla sowieckich historyków niemożliwe było oddanie palmy pierwszeństwa w tworzeniu światowego pokoju „Krwawemu Mikołajowi”. Interesujące, że artykuł poświęcony otwarciu pokojowej konferencji w Hadze w dniu narodzin rosyjskiego imperatora zatytułowany był „Wielka inicjatywa” („Петербургская газета”, 7 мая, 1899 г., № 123, s. 2), tak samo, jak później W. I. Lenin zatytułował swój artykuł o komunistycznych subotnikach. „Wielka inicjatywa" Mikołaja II przykuwa uwagę swoją ewangeliczną łaskawością. Owo dążenie do wnoszenia w życie państwa i do swego światopoglądu chrześcijańskich zasad religijno-moralnych zawsze wyróżniało zewnętrzną politykę imperatora Mikołaja II, pomimo że podczas jego panowania Rosja brała udział w dwóch krwawych wojnach, które nie wymazały z kart historii pokojowych inicjatyw Mikołaja II. Jak napisano w zebranych materiałach pt. „Жития Св. Благочестивейшего Царя-Мученика Николая Великого Страстотерпца”: „Желающие в этом убедиться, могут посетить Центральные Учреждения Организации Объединенных Наций в гор. Нью-Йорке, где в здании Секретариата, на первом этаже, на почетном и видном месте, выставлена для всеобщего обозрения подлинная грамота с призывом ко всем государствам принять участие в Гаагской мирной конференции 1899 года, за собственноручной подписью Императора Всероссийского Николая II" (Алферьев Е. В., 1983).

W nieurodzajnym roku 1891 Aleksander III ustanowił syna głową Komitetu ds. organizacji pomocy głodującym. Przyszły car na własne oczy widział ludzkie nieszczęście i nieustannie trudził się, aby ulżyć cierpieniom swego narodu. Miłosierdzie cierpiętnika cara Mikołaja w oczach większości było po prostu carskim miłosierdziem.

W ocenie działań i zamiarów carskich osób, zarówno ze strony im współczesnych, jak i historyków wywodzących się z ich potomków, zwykle dominuje niecerkiewny punkt widzenia: nad prawdą przeważa potrzeba, nad potrzebą - czynnik możliwości władczych i materialnych. Wszystko, co może służyć zbawieniu duszy, zwykle nie jest brane pod uwagę podczas rozważania wykonywanych przez niego dla innych tzw. służbowych obowiązków. Jak to mówią, car może wszystko. Zawarta jest w tym pokusa cudzej władzy. W przezwyciężeniu tej pokusy i ujrzeniu świętości carskiego męczennika pomaga rozważanie o dążeniu imperatora do wartości ewangelicznych. Św. Izaak Syryjczyk w 5. słowie ascetycznym wyraźnie zauważył, $\dot{z ̇ e}$ „не те только мученики, которые прияли смерть за 
веру во Христа, но и те, которые умирают за соблюдение заповедей Христовых" (Исаак Сирин, авва, 1993, s. 26). W tych słowach świętego podkreślony jest trud drogi cierpiętników.

We współczesnym pojmowaniu męczeństwo zawsze wiąże się z fizycznymi doświadczeniami, zaś błogosławieństwo dane męczennikom jest tylko domyślne. Zachowywanie przykazań Chrystusowych w warunkach dominacji zsekularyzowanych wartości świeckich stanowi duchowe męczeństwo i cierpienie, tj. „,страстотерпчество страстоносцев".

Po abdykacji monarchy Mikołaja II nastapiła reakcja społeczeństwa. Życie w nim stało się burzliwe. „Горько оплакивали мы отречение Государя были на удивление большинству, ожидающему каких-то новых неслыханных земных благ. Помню, как в церкви хорошо знакомый мне средних лет священник, казавшийся всегда весьма благочестивым и духовным, читал акт об отречении. Церковь была полна, все пришли нарядные и с оживленными лицами. Начиная со священника, все торжествовали, радовались и приветствовали этот приговор России, поздравляя друг друга. Я же горько плакала" (Урусова Н. В., 2008, s. 17).

Uczucie smutku towarzyszyło metropolicie Eulogiuszowi (Gieorgijewskiemu): „Несмотря на все ликование вокруг меня, на душе моей лежала тяжесть. Вероятно, многие испытывали то же, что и я. Манифест об отречении Государя был прочитан в соборе, читал его протодиакон - и плакал. Среди молящихся многие рыдали. У старика городового слезы текли ручьем..." (Путь моей жизни. Воспоминания митрополита Евлогия (Георгиевского), изложенные по рассказам T. Манухиной, Москва, 1994, s. 263).

Nie wszyscy od razu dowiedzieli się o abdykacji monarchy. Na przykład N. D. Żewachow dowiedział się dopiero 3 marca. „Как ни феерична была декорация «бескровной» революции, залившей потоками крови всю Россию, как ни дико было это безумное ликование масс и велико упоение властью бездарных проходимцев, явившихся на смену прежней власти, как ни трескучи были их громовые речи, их истерические выкрики о завоеваниях революции, с призывами углублять эти завоевания, однако не нужно было быть психологом, чтобы заметить, что вся эта декорация, вся эта шумиха и приемы, коими пользовались «завоеватели», скрывали за собой не силу, а слабость, и что творцы революции, до момента отречения Государя от Престола, чувствовали себя не героями дня, а кандидатами на виселицу" (Воспоминания товарищза обер-прокурора Святейшего Синода князя Н. Д. Жевахова, Т. 1, 1993, s. 301-302).

„Затем поползли слухи о вынужденном отречении: я и этого ждал, знал сердцем, как там, в центре революции, ненавидели именно Царя, как там хотели не конституции, а именно свержения Царя, какие жиды там давали направление" (Булгаков С. Н., 1946, s. 92).

Natychmiast zaczęły pojawiać się zmiany w kraju. Nie tylko stolica, ale również inne miasta i miejscowości odczuwały następujący upadek monarchicznego systemu rządów. „Со дня отречения начались безобразные эксцессы в городе. Пьяные солдаты стали хозяевами положения: они били беспорядочно во все колокола, а в Ярославле церквей было много и колоколов много. Стали являться в квартиры, требуя продуктов и безобразничая" (Урусова Н. В., 2008, s. 18).

Metropolita Beniamin (Fiedczenkow) opisuje, jak bardzo te wydarzenia odcisnęły na nim swoje piętno: „Когда получили известие об отречении царя от власти, о передаче власти Михаилу Александровичу, я обязан был сказать по этому случаю соответствующее поучение. Но у меня тогда не было никаких сил торжествовать. C удалением царя и у меня получилось такое впечатление, будто бы из-под ног моих вынули пол и мне не на что было опереться. Еще я ясно узрел, что дальше грозят ужасные последствия. Я почувствовал, что теперь поражение нашей армии неизбежно. И не стоит даже напрасно молиться о победе..." (Вениамин Федченков, митрополит, 1994, s. 152).

Wyrażając opinię na temat nieuchronności abdykacji, generał Jurij Daniłow uważa: „Я не думаю, чтобы почин в вопросе об отречении мог иметь какое-либо решающее значение, ибо мысль о неизбежности такового отречения зарождалась у массы людей, и притом у части их - задолго даже до возникновения сейчас описываемых событий. Вытекала же она из оценки ими реальной обстановки того времени” (Данилов Ю. Н., b.r.w.).

Abdykujący imperator przekazał ster władzy swemu bratu Michałowi Aleksandrowiczowi. Jego osoba była nieznana większości ludzi. Co wielki książę reprezentował sobą? Generał Daniłow opisuje go jako człowieka niezdolnego do rządzenia tak wielkim państwem: „Я не сказал бы, что Великий Князь Михаил Александрович производил впечатление очень способного человека, но он проявлял любознательность и к нему влекли его необыкновенная скромность и деликатность" (Данилов Ю. H., b.r.w.). Taka osoba mogłaby rządzić w takim imperium, w którym aparat władzy byłby wyraźnie określony. Niestety, w tamtym czasie tak nie było.

Będąc świadomym własnego nieprzygotowania do bardzo odpowiedzialnego zadania, książę Michał Aleksandrowicz nie przyjął tronu carskiego. Rozwiązanie kwestii ustroju państwowego Rosji przekazał decyzji przyszłego Zgromadzenia Ustawodawczego (Konstytuanty), którego powołanie powinna była zapewnić władza tymczasowa.

Mikołaj II, dowiedziawszy się o nieprzyjęciu tronu przez Michała Aleksandrowicza, otrzymał jeszcze większy cios, tym razem od krewnego. „Алексеев пришёл с последними известиями от Родзянко. Оказывается, Миша отрекся. Его манифест кончается четырехвосткой для выборов через 6 месяцев Учредительного Собрания. Бог знает, кто надоумил его подписать такую гадость! В Петрограде беспорядки прекратились - лишь бы так продолжалось дальше" (Дневник Николая II, b.r.w.). 
Tym sposobem, w krótkim okresie kraj usłyszał dwa manifesty $\mathrm{w}$ sprawie odrzucenia ustroju monarchicznego. „Закончив чтение манифеста Государя, генерал Крымов стал читать манифест Великого Князя Михаила Александровича. После первых же фраз я сказал начальнику штаба: «Это конец, это анархия». Конечно, самый факт отречения Царя, хотя и вызванный неудовлетворенностью общества, не мог, тем не менее, не потрясти глубоко народ и армию. Но главное было не в этом. Опасность была в самой идее уничтожения монархии, исчезновении самого Монарха" (Врангель П. H., b.r.w.). Dalej generał P. N. Wrangel objaśnia, na czym polega tragedia odrzucenia ustroju. „Последние годы Царствования отшатнули от Государя сердца многих сынов отечества. Армия, как и вся страна, отлично сознавала, что Государь действиями Своими больше всего Сам подрывает престол. Передача Им власти Сыну или Брату была бы принята народом и армией не очень болезненно. Присягнув новому Государю, русские люди, так же как испокон веков, продолжали бы служить Царю и родине и умирать за «Веру, Царя и Отечество». Но в настоящих условиях, с падением Царя, пала сама идея власти, в понятии русского народа исчезли все связывающие его обязательства, при этом власть и эти обязательства не могли быть ничем соответствующим заменены” (Врангель П. Н., b.r.w.).

Można zadać pytanie: „Dlaczego wielka dobroczynność niosących pokój?”. „Потому, что она не о том только печется, что связано с жизнью самого подвижника, но стремится как бы самое небо низводить на землю” (Антоний Храповицкий, митрополит, 1989, s. 131), aby zamiast wrogości był pokój - pisał współczesny imperatorowi metropolita Antoni (Chrapowicki). Opisuje on, w jaki sposób należy podążać za tym przykazaniem: „Должно не только поступать со всеми дружелюбно, даже с уступкою своего права, ради сохранения мира (если только сие не противно долгу и ни для кого не вредно), но стараться и других враждующих между собою примирять, поколику имеем возможность, а когда не можем, - молить Бога о их примирении" (Антоний Храповицкий, митрополит, 1989, s. 131). W podobnie konkretny sposób mówi św. Jan Kronsztadzki: „Должны поступать со всеми дружелюбно, не подавать причины к несогласию и предотвращать его всеми мерами, если оно случится из-за чего-либо, например, из-за оскорбления, несправедливости чьей-либо, или из-за посягательства кого-либо на нашу собственность или права, - всеми мерами стараться это несогласие пре- кращать, хотя бы при этом нужно было пожертвовать и чем-либо нам принадлежащим, например, нашей собственностью, нашей честью, или первенством, если только это не противно нашему долгу, службе, и никому не вредно" (Сергиев И., 1994, s. 211-212). Jak widzimy, pokojowa działalność abdykującego imperatora nie była zauważalna przez jego współczesnych. Oceniając zagadnienie prawosławnego stosunku wobec aktu abdykacji przyjmowano dowody w większości kanoniczne, a następnie specyficznie historyczne w świetle racjonalności, choć nie dostrzegano motywów i usposobienia cara w duchu Ewangelii.

Wygnanie i prześladowanie cara oraz obrzucanie go oszczerstwami były znane wszystkim. Można powiedzieć, że na tych informacjach wychowywały się porewolucyjne pokolenia. Jako pierwsi zapoznali się z nimi współcześni, gdy „печать наполнилась самыми лживыми и гнусными пасквилями по адресу отрекшегося Самодержца" (Воейков В. Н., 1994, s. 213), о czym świadczy także przegląd „Петроградской газеты” z marca 1917 roku. W związku z taką informacją, zainteresowanie sprawą carską wzrosło sześciokrotnie - ze średniej względnej częstotliwości 1,16 w styczniu do 7,22 w marcu.

Zasadniczym źródłem tych informacji, przy bezpośredniej i pośredniej ofierze cara, była literatura pamiętnikowa, tworzona przez jemu współczesnych w celu usprawiedliwienia i wywyższenia samych siebie. Wybór wspomnień z interpretacji marksistowskich historyków stworzył nam obraz „Mikołaja Krwawego”, bliskiego i zniewolonego. Obraz ten został uwieczniony w kapitalnej „,Большой Coветской энциклопедии”. Na przykład: ,y Николая II были недостаточные для государственного деятеля умственные способности, он отличался безволием, которое сочеталось с упрямством в решении вопросов, связанных с его личным престижем" (Большая Советская Энциклопедия, 1974, s. 11). Charakteryzuje się on „проведением репрессивных мер на протяжении всего царствования - «кровавое воскресение», карательные экспедиции и военно-полевые суды 1905-1907 годов" (Большая Советская Энциклопедия, 1974, s. 11). W podobny sposób postrzegali cara również jego liberalni współcześni.

„По мере того, как праведные за свою правду терпят на земле поношения, гонения, лишения, - увеличивается и их награда на небесах; здесь они часто лишаются всего, там получают с избытком все: нетленную славу, нетленный венец, неоскудевающее сокровище, непрестанное веселие, нескончаемое царство" (Сергиев И., 1994, s. 226). Na tym polegało wybraństwo męczennika cara Mikołaja.

\section{Bibliografia}

Akty Svâtejšego Tihona, Patriarha Moskovskogo i vseâ Rusi, pozdnejšie dokumenty i perepiska o kanoničeskom preemstve vysšej cerkovnoj vlasti, Sost. M.E. Gubonin, M., 1994. [Акты Святейшего Тихона, Патриарха Московского и всея Руси, позднейшие документы и переписка о канони- ческом преемстве высшей церковной власти, Сост. М.Е. Губонин, М., 1994]

Alfer'ev, E.V. (1983), Imperator Nikolaj II kak čelovek sil'noj voli, Džordanvill'. [Алферьев, Е.В. (1983), Император Николай II как человек сильной воли, Джорданвилль] 
Antonij (Hrapovickij), mitropolit (1989), Opyt hristianskogo katehizisa, Victoria, Australlia, Avstralijsko-Novozelandskaâeparhiâ RPCZ. [Антоний (Храповицкий), митрополит, Onыт христианского катехизиса (1989), Victoria, Australlia, Австралийско-Новозеландская епархия РПЦ3,]

Bol'šâ Sovetskaâ Ėnciklopediâ, 3 izd. T. 18, M., Sovetskaâ Ènciklopediâ, 1974, s. 11. [Большая Советская Энциклопедия, 3 изд. Т. 18, М., Советская Энциклопедия, 1974, s. 11.]

Bulgakov, S. N., protoierej (1946), Avtobiografičeskie zametki, Paris. [Булгаков, С. Н., протоиерей (1946), Автобиографические заметки, Paris]

Veniamin (Fedčenkov), mitropolit (1994), Na rubeže dvuh èpoh, М. [Вениамин (Федченков), , митрополит (1994), На рубеже двух эпох, М.]

Voejkov, V. N. (1994), S carem i bez carâ. Vospominaniâ poslednego dvorcovogo komendanta gosudarâ imperatora Nikola $\hat{a}$ II, М. [Воейков, В. Н., С ияарем и без изаря. Воспоминания последнего двориового коменданта государя императора Николая II, М.]

Vospominaniâ tovariŝa ober-prokurora Svâtejšego Sinoda knâzâ N. D. Ževahova (1993), Т. 1, М. [Воспоминания товарища обер-прокурора Святейшего Синода князя Н. Д. Жевахова, T. 1, M., 1993, s. 301-302.]

Vrangel', P. N., ZAPISKI (noâbr' 1916 g.- noâbr'1920 g.), [w:] http://www.ukrstor.com/ukrstor/wrangel-zapiski1.html (dostęp: 04.05.2016). [Врангель, П. Н., ЗАПИСКИ (ноябрь 1916 2.- ноябрь 1920 г.), [w:] http://www.ukrstor.com/ ukrstor/wrangel-zapiskil.html (dostęp: 04.05.2016).]

Vysočajšij Manifest, „Peterburgskaâ gazeta” 9 maâ, 1968 g., № 62, s. 1. [Высочайший Манифест, „Петербургская газета" 9 мая, 1968 г., № 62, s. 1.]

Danilov,Û. N., Moi vospominaniâ ob Imperatore Nikolae II-om i Vel. Knâze Mihaile Aleksandroviče [w:] http://ldn-knigi.lib. ru.html (dostęp: 19.11.2017). [Данилов, Ю. Н., Мои воспоминания об Императоре Николае II-ом и Вел. Князе Михаиле Александровиче, [w:] http://ldn-knigi.lib.ru.html (dostęp: 19.11.2017).]

Dnevnik Nikolaâ II, [w:] http://www.unilib.neva.ru/d1/327/ Theme_9/Sources/civil_war/Sbornik_of_docs.htm (dostęp: 06.11.2017). [Дневник Николая II, [w:] http://www.unilib. neva.ru/dl/327/Theme_9/Sources/civil_war/Sbornik_of_ docs.htm (dostęp: 06.11.2017).]
Doklad mitropolita Krutickogo i Kolomenskogo Ûvenaliâ, predsedatelâ Sinodal'noj Komissii po kanonizacii svâtyh (2000), [w:] Ûbilejnyj Arhierejskij Sobor Russkoj Pravoslavnoj Cerkvi, 13-16 avgusta 2000 goda. Sbornik dokladov i dokumentov, SРВ. [Доклад митрополита Крутицкого и Коломенского Ювеналия, председателя Синодальной Комиссии по канонизачии святых, [w:] Юбилейный Архиерейский Собор Русской Православной Церкви, 13-16 августа 2000 года. Сборник докладов и документов, СПб., 2000.]

Eršov, S.A. (2000), Čitaâ žitiâ svâtyh..., [w:] Russkie svâtye: 1000 letrusskoj svâtosti, Sankt-Peterburg, Azbuka. [Ершов, С.А., Читая жития святых..., [w:] Русские святые: 1000 лет русской святости, Санкт-Петербург, Азбука, 2000, s. 12-13.]

Isaak Sirin, avva, Slova podvižničeskie (1993), М. [Исаак Сирин, авва, Слова подвижнические, М., 1993]

„Peterburgskaâ gazeta” 6-25 maâ, 1899 g., №№ 122-140, s.101117. [„Петербургская газета” 6-25 мая, 1899 г., №№ 122140, s. 101-117.]

„Peterburgskaâ gazeta”, 7 maâ, 1899 g., № 123, s. 2. [„Петербургская газета", 7 мая, 1899 г., № 123, s. 2.]

Put' moej žizni. Vospominaniâ mitropolita Evlogiâ(Georgievskogo), izložennye po rasskazam T. Manuhinoj (1994), M. [Путь моей жизни. Воспоминания митрополита Евлогия (Георгиевского), изложенные по рассказам Т. Манухиной, М., 1994]

Sergiev Ioann, protoierej (Kronštadtskij) (1994), Besedy o blaženstvah evangel'skih, [w:] Polnoe sobranie sočinenij protoiereâ Ioanna Il'iča Sergieva, T. 1., SPB., izdatel'stvo L.S. Âkovlevoj, 1994, s. 211-212. [Сергиев Иоанн, протоиерей (Кронштадтский), Беседы о блаженствах евангельских, [w:] Полное собрание сочинений протоиерея Иоанна Ильича Сергиева, Т. 1., СПб., издательство Л.С. Яковлевой, 1994, s. 211-212.]

Urusova, N. V., knâginâ (2008), Materinskij plač' Svâtoj rusi, M., Russkij Palomnik, 2008, s. 17. [Урусова, Н. В., княгиня, Материнский плачь Святой Руси, М., Русский Паломник, 2008, s. 17.]

Ûbilejnyj Arhierejskij Sobor Russkoj Pravoslavnoj Cerkvi, 13-16 avgusta 2000 goda. Sbornik dokladov i dokumentov (2000) SPB., 2000, s. 79. [Юбилейный Архиерейский Собор Русской Православной Церкви, 13-16 августа 2000 года. Сборник докладов и документов, СПб., 2000, s. 79.]

Rozmiar artykułu: 0,6 arkusza wydawniczego 
ISSN 1508-7719

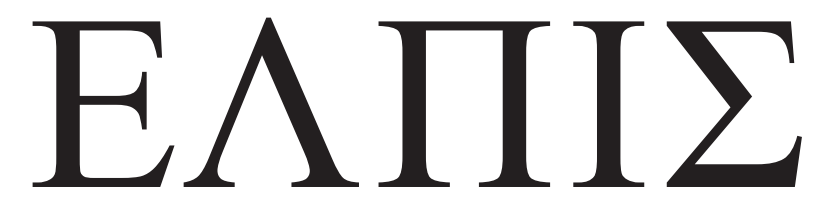

CZASOPISMO TEOLOGICZNE KATEDRY TEOLOGII PRAWOSŁAWNEJ UNIWERSYTETU W BIAŁYMSTOKU

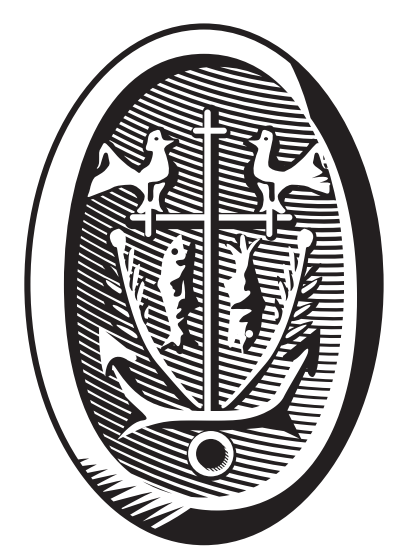

ADRES REDAKCJI

ul. Ludwika Zamenhofa 15, 15-435 Białystok, Polska tel. 85 745-77-80, e-mail: elpis@uwb.edu.pl www.elpis.uwb.edu.pl 